\title{
Re-Distribution and Public Governance - The Politics of Higher Education in Western Europe
}

\begin{abstract}
Many studies analysing partisan politics assume differing preferences based on a party's ideological background without providing matching empirical analysis. This is especially true for more specialised policy areas like higher education policy, which are not included in studies such as the Comparative Manifestos Project. While the limited existing literature inadequately focuses only on the re-distributive dimension of partisan competition, the main theoretical argument of this article is that in order to fully capture partisan dynamics, it is necessary to include a second analytical dimension, which addresses the question how higher education is governed. Based on this framework and the ideologies of different party families, theoretical expectations for partisan preferences are deduced. Subsequently, these expectations are tested using originally coded election manifestos and a detailed qualitative content analysis for all relevant parties in four European countries (the UK, Germany, Norway and the Netherlands).

The findings show that parties do hold differing preferences which can be structured along the two dimensions. While many parties fulfil the theoretical expectations, there is also a fair amount of variation within party families, which can be explained by pointing to the importance of institutions, their legacies and resulting constrains for the formation of partisan preferences.
\end{abstract}

\section{Keywords}

Political parties, partisan preferences, higher education policy, public governance, New Public Management, election manifestos

\section{Introduction}

In the partisan competition literature the question whether parties matter for policy output is a prominent topic. The most common approach in these studies is to link the ideological composition of governments to public spending changes. Thus, the 'parties matter' literature assumes that measure of the parties' ideological position are in line with respective partisan preferences, as laid out in election manifestos. While there is ample literature analyzing preferences for core policy 
areas, such as labor market or fiscal policy (e.g. Volkens et al., 2014), we know considerably less about partisan positions in more specialized policy areas. This article contributes to the understanding of partisan policy-making by investigating the partisan competition in higher education (HE) policy.

While there are many assumptions on party positions in education policy, there are so far only a few studies that empirically analyze partisan preferences on education (e.g. Ansell, 2010; Busemeyer et al., 2013), and even less that focus specifically on HE (Garritzmann, 2014; Garritzmann, 2015). All of these have in common, that they analyze partisan dynamics along one dimension capturing the re-distributive aspects of HE. However, the central argument of this article is that the existing literature falls short in its analysis, and contrary to their approaches, it is argued that parties can be expected to differ in their preferences along two dimensions: the re-distributive one and another dimension addressing public governance of HE. Especially the second dimension represents a part of the political conflict on social policies in general and HE specifically that has not been sufficiently studied. This is problematic because with the rise of New Public Management (NPM) and its existing variations partisan conflicts on the control over public sectors emerged (Gingrich, 2011; Pollitt, 2001). This article develops several theoretical expectations concerning partisan preferences in HE for different party families along two analytical dimensions, and then puts these to the test. To do so, the article uses a detailed qualitative content analysis and original coding of election manifestos of all relevant parties in four European countries: Germany (North Rhine-Westphalia), Norway, the Netherlands, and the UK.

The remainder of the article will start with presenting the two-dimensional theoretical framework, followed by the presentation of the data and methods employed. Next the party positions in HE policy will be discussed. The conclusion presents the results, highlights their relevance and offers possible further research. 


\section{Partisan preferences in higher education}

The idea of differing partisan preferences links back to the partisan hypothesis (Hibbs, 1977), according to which differing constituencies have different preferences that are aggregated by parties and, once parties are in government, preferences are transferred into policies favoring the respective constituency. Consequently, it is possible to formulate expectations on partisan preferences based on a party's ideology and the interests of its constituency.

While HE is an area that could be perceived as outside of the realm of partisan competition, since educational expansion is described as a world phenomenon (Schofer and Meyer, 2005), several studies point to partisan effects on HE policy outputs (e.g. Busemeyer, 2009; Ansell, 2010; Rauh et al., 2011). This coincides with HE being characterized by increased political saliency due to a larger share of public budgets being spent on it, discussions on the knowledge economy, and HE being expected to deliver solutions for other policy areas (Christensen et al., 2014).

There is only limited existing literature on partisan preferences in education and $\mathrm{HE}$, and most studies use data and coding of the Comparative Manifestos Project (CMP) for their analyses (e.g. Ansell, 2010; Busemeyer et al., 2013). This is problematic as the CMP coding differentiates neither between levels of education nor between support for educational expansion and improvement. As, contrary to the situation with respect to primary or secondary education, access to tertiary education is skewed towards the more affluent part of the population (Ansell, 2010; Fernandez and Rogerson, 1995), the difference between levels of education, and the desire for educational expansion versus educational improvement thus creates meaningful dissimilarities. Therefore, a more refined approach and more empirical work are necessary to uncover partisan preferences in HE policy.

Furthermore, studies that analyze partisan preferences on HE policy do so using one analytical dimension, which addresses whether HE policy is used as a tool for re-distribution (e.g. Ansell, 2010; Garritzmann, 2014). Whereas the authors analyzing HE policy along the re-distributive 
dimension are correct in their assessment that political parties differ in this respect, a fact also supported by results from studies analyzing differences in policy outcomes (e.g. Busemeyer, 2009; Rauh et al., 2011), this is not the only dimension that structures party competition in HE.

Another dimension where political parties show differences is linked to the question how and by whom the control over the HE sector is exercised (AUTHOR). This dimension stems from increased political competition on public governance in the aftermath of the rise of NPM and resulting variations in public sector reforms (Pollitt, 2001; Gingrich, 2011). This conflict dimension is important, because the question in how far the HE sector is steered centrally or more decentralized is related to questions of the responsiveness of the sector to public demands, and the efficiency of its service delivery. Additionally, while shifts in the governance of a public sector are of low visibility to voters and seem rather technical, they still can yield significant effects (Gingrich, 2015).

\section{The re-distributive dimension}

The re-distributive dimension of party conflicts in HE addresses its potential for socio-economic change. HE can serve as a tool for re-distribution, because it, for example, offers the possibility to upgrade one's skills, limit the threat of unemployment, and also provides the opportunity for social mobility (Ansell, 2010). Re-distributive activities by the government are usually linked to enlarged public spending in a given public sector. Since several studies have found that the partisan composition of a government also matters for the level of public HE spending (e.g. Schmidt, 2007; Busemeyer, 2009), it can be assumed that HE has re-distributive potential.

The expectation of the partisan hypothesis towards left parties is that they, generally speaking, aim at increasing the equality of opportunities in a given society and support re-distribution, to favor their constituents which mostly have a lower socio-economic background (Boix, 1997). Right parties, in contrast, are expected to oppose re-distribution, as their constituencies stem mainly from higher socio-economic groups, and it is in the self-interest of the right's electorate to preserve their advantageous societal position. Thus, right parties support hierarchical societies and, in the 
case of Christian Democrats, put a greater emphasis on the responsibilities of families instead of the state (Kalyvas and van Kersbergen, 2010; Heywood, 2007).

In $\mathrm{HE}$, contrary to other more direct forms of re-distribution such as unemployment benefits, it is not possible to simply link parties of the political left with more public spending, as HE is not a public good equally accessible by all (Ansell, 2010). Rather, participation in HE is skewed towards the more affluent part of the population and socio-economic background of students is positively related to their likelihood of attending university (Ansell, 2010; Fernandez and Rogerson, 1995). This means that the re-distributive capacity of $\mathrm{HE}$ is dependent on the existing level of participation.

If a HE system is restrictive and has low participation rates, then it is mainly the more affluent electorate of right parties that participates. Therefore, enlarged public spending in this sector without significantly increasing participation rates, would be a tool of reverse re-distribution (Rauh et al., 2011). In contrast, if a HE system is expansive with high participation rates, left parties favor higher public spending on HE because of its re-distributive capacities (Ansell, 2010). At the same time, left parties in general favor a wider access to $\mathrm{HE}$, both concerning the number of students and the entrance requirements needed, as this allows a greater participation of their electorate.

Another factor influencing the re-distributive potential is private HE spending. Increasing or introducing tuition fees allows shifting some of the costs of HE to its users. Left parties should generally oppose private HE funding, as it represents a barrier for their electorate to participate in HE as it is more debt-averse (Callender and Jackson, 2005). Contrary, the constituents of right parties are less sensitive to the effects of increased tuition, especially in situations where the quality of HE might be threatened. Right parties might even use increased private HE spending to limit access to HE and protect their electorate's labor market advantages (Wolf and Zohlnhöfer, 2009). Finally, another way to improve HE's re-distributive capacities is a generous student support system. This equalizes the socio-economic differences between (potential) students, incentivizes 
especially students from lower socio-economic backgrounds to participate in $\mathrm{HE}$, and thus allows for more social upward mobility (Garritzmann, 2014). Left parties therefore favor the creation and expansion of student support systems, while right parties oppose expansive student support schemes as their electorate profits less from it, and a less exclusive access to HE threatens their existing advantages.

In sum, the re-distributive dimension in HE describes whether a party favors an expansive HE system or rather a restrictive one. Four main indicators are relevant to assess this:

1. Public spending on HE;

2. Access to HE;

3. Private spending on $\mathrm{HE}$;

4. Student support.

Based on this, one can formulate expectations on partisan positions. Social Democrats (SD) can be expected to support an expansive HE system while limiting private HE spending. This provides redistributive advantages for their debt-averse electorate and offers the possibility for social mobility (Busemeyer, 2009). Rooted in the idea of the individual's responsibility to use their skills to improve their socio-economic status without state interference, and that the education system should cater to the labor markets' needs supporting today's knowledge economy, Liberal Parties (LP) can be expected to favor an expansive HE system. However, due to the Liberals' focus on the individual and their preference for limited public spending, it can be expected that they favor some form of individual costs for attending HE (Kirchner, 1988).

Christian Democrats (CD) can be expected to be in favor of a more restrictive HE system, because of their desire to limit re-distribution and protect the their electorate, but also because of their preferences for families as the main support structure for children (Kalyvas and van Kersbergen, 2010). Conservative Parties (CP) can be expected to shield their electorate from re-distribution. Therefore, they prefer a restrictive HE system that limits public spending and protects their 
electorate's labor market advantage that they have because of the skewed access to HE (Rauh et al., 2011).

Comparable expectations are harder to formulate for other party families. Anti-establishment parties (AEP) at the left and right fringe of the spectrum are known for having only limited positions concerning HE (Ansell, 2010: 137ff). However, as AEPs of the left ideologically favor re-distribution and AEPs of the right often have an electorate with a lower socio-economic background, it can be expected that AEPs favor an expansive HE system, as their constituents are more likely to participant. Green parties (GP) are harder to place because their electorate is diverse but increasingly drawn from highly educated strata, while their election manifestos hold different positions having both politically left and right characteristics (Rauh et al., 2011). However, an analysis of expert survey data including the placement of GPs on the question of re-distribution through HE shows that they favor an expansive HE system (Garritzmann, 2014).

\section{The control dimension}

Since the early 1980s, the relationship between the state and public sectors has changed, through NPM and post-NPM reforms (Christensen, 2011) and the increasing relevance of markets as governance mechanisms (Gingrich, 2011). While there is strong discursive convergence, there is divergence with regards to implementation of reforms, due to institutional legacies as well as decisions by actors (Pollitt, 2001). Thus, opening up the state - public sector relationship has led to conflicts concerning, who holds effective control over the public sector, which encouraged political parties to compete on this issue (Gingrich, 2011).

The second analytical dimension therefore addresses the question how the HE sector is controlled. It links to studies identifying conflicts between libertarian and communitarian values concerning the distribution of authority, power, and autonomy (Kriesi, 2010). The dimension spans between centrally controlled HE system and systems where the governance is decentralized. 
In HE studies a prominent conceptualization of governance is Clark's triangle of coordination (Clark, 1983). He distinguishes three forces whose interplay shapes the state-HE relationship: the state, academic oligarchy, and the market. The concrete arrangement with regard to the role of each of the three factors in governing HE defines the level of authority of the state.

In a more refined conceptualization Olsen (1988) structures public governance along two dimensions, one capturing the distinction between shared goals versus conflicting self-interests and a second addressing voluntary decisions by rational actors versus deterministic environments. The resulting four governance modes have been transferred by Gornitzka and Maassen (2000) to HE: (1) the sovereign rationality-bounded mode, where the government is the dominant actor, (2) the institutional mode, where public governance is focused on autonomous universities, (3) the corporate-pluralist mode, where public governance is negotiated between stakeholders, and (4) the supermarket mode, which uses market mechanisms for governance of HE.

These four different forms of political control over HE lead to differing power relations between the state and $\mathrm{HE}$ and thus can be used as indicators to assess how centralized governance of $\mathrm{HE}$ is:

1. The dominance of the government in controlling HE;

2. Autonomy of HE institutions to steer themselves;

3. Governance through negotiation between stakeholder groups;

4. Governance based on market mechanism.

While the autonomy of HE institutions and the use of market mechanisms indicate decentralized HE governance, the dominance of the state and the negotiations between stakeholder groups are more centralized forms of control.

Based on their ideological preference for an active state that shapes the life of its citizens (Busemeyer, 2009), SDs favor a centralized control of HE, and a dominant role of the government. This instrumental approach also supports their re-distributive endeavors. In a situation where 
direct government control of $\mathrm{HE}$ is not feasible, it can be combined with the inclusion of stakeholders that are close to their constituents, such as students or trade unions.

CDs have two competing preferences on public governance. On the one hand, they are in favor of subsidiarity and giving competences to local institutions (Kalyvas and van Kersbergen, 2010), which calls for the support of greater autonomy of HE institutions. On the other hand, they put an emphasis on high quality and qualitative homogeneity of $\mathrm{HE}$, which demands the state to have a more active role (Kalyvas and van Kersbergen, 2010). Therefore, they take a middle position concerning the centrality of HE governance.

CPs support more de-centralized control, because they prefer smaller state structures and more streamlined public services, combined with forms of market competition (Boix, 1997). Furthermore, CPs are not opposed to heterogeneity in the quality of HE given their preference for markets. Therefore, they favor autonomous HE institutions that compete in the marketplace.

Just like CPs, LPs support streamlined state structures and market competition. They see heterogeneity in the quality of $\mathrm{HE}$ not as a problem for the state but as something which is regulated through market mechanisms (Kirchner, 1988), and they support the autonomy of HE institutions to enable them to compete freely. Thus, LPs can be expected to favor decentralized HE governance.

GPs, due to their more diverse electorate (Rauh et al., 2011), favor including different stakeholder groups. At the same time, their preference for a higher level of re-distribution makes them open for an active role of the government in public governance (Garritzmann, 2014), therefore they prefer centralized HE governance. AEPs at the left and right fringes can be expected to prefer the government as the dominant actor in HE governance and thus support centralized control over HE. While AEPs from the left do so because of their firm belief in a strong and active state (Boix, 1997), AEPs of the right distrust HE institutions to steer themselves, because they do not have a strong representation of their electorate in these institutions. 
Table 1. Theoretical expectations towards partisan preferences in HE.

\begin{tabular}{|c|c|c|c|}
\hline & \multicolumn{2}{|c|}{ Re-distributive dimension } \\
\hline & & Expansive HE system & Restrictive HE system \\
\hline \multirow[t]{2}{*}{ Control dimension } & $\begin{array}{l}\text { Centralized control over } \\
\text { HE sector }\end{array}$ & SD, AEP, GP & \\
\hline & $\begin{array}{l}\text { De-centralized control } \\
\text { over HE sector }\end{array}$ & LP & $\mathrm{CD}, \mathrm{CP}$ \\
\hline
\end{tabular}

While the concepts that informed the above expectations are key explanatory factors for partisan positions, they are not the only ones discussed in the literature. However, in the interest of available space and a parsimonious conceptual model, this study will put its focus on party ideology and constituents as main explanatory factors. To acknowledge the role of additional factors, some of them will be briefly discussed.

First, partisan preferences are formulated in relation to existing $\mathrm{HE}$ systems and related institutional structures. As radical reforms of existing institutions and policies are often politically costly (Gingrich, 2015), the existing structure of the HE system and existing policies create legacies and path dependencies that constrain partisan preferences (Gingrich, 2011; Ansell, 2010). Second, from a micro perspective, the existing institutional structure of the HE system also shapes the preferences of voters through feedback effects (Garritzmann, 2015; Pierson, 1993), which in turn makes it more costly for parties to pursue radical changes and thus might constrain partisan preferences. Finally, the polarization of the party system, i.e. the number of competing parties, affects partisan competition, as more active parties lead to more polarization and competition along multiple cleavage lines (Sartori, 1976). 


\section{Methods and data}

There are different methodological approaches used to analyze partisan preferences. The most dominant one is the quantitative content analysis by human coders employed by the CMP. Even though the CMP data was used by Ansell (2010) and Busemeyer et al. (2013) to analyze higher education, it is problematic to do so, because the coding only measures educational expansion without separating different levels of education. Since HE has a different participation structure than primary or secondary education, the coding is not very helpful here. Also more automated approaches using words as data are not suitable, as they need reference documents to create a baseline to measure political positions (Laver et al., 2003). Such a baseline does not exist for the area of HE policy. A more promising option are expert surveys that provide data on partisan preferences on HE (Garritzmann, 2014). However, they also have methodological problems since it is unsure whether the experts' estimates are based on partisan preferences or observed party behavior (Volkens, 2007)

This study uses a qualitative approach with a more refined coding scheme that was specifically generated to analyze HE policy, and which guides a qualitative content analysis. This is considered to be an appropriate method, as the study is more explorative and aims at getting a detailed understanding of preferences in HE as presented in election manifestos. Therefore, the higher level of internal validity linked to qualitative content analysis is seen as an advantage, although it comes at the cost of external validity of the findings.

The analysis uses a coding scheme based on the indicators presented earlier. For each of the eight indicators that are the basis for measuring the two dimensions three codes were used, covering an 
increase, decrease or stability of each indicator. ${ }^{1}$ Each document was coded by a single coder using the MAXQDA software, ${ }^{2}$ and each relevant quasi-sentence could be coded with one or more codes.

The corpus consists of manifestos of all relevant parliamentary parties in the four countries for two recent elections that led to different governments. Two elections were chosen to enlarge the available data and increase the robustness of the study. Furthermore, the focus is on recent elections since the interest is to map partisan differences in today's HE policy and not to trace historical developments. A party is considered relevant if it is represented in the parliament in both instances and receives at least $2.5 \%$ of the votes. Election manifestos were chosen as data, because they are public documents, geared towards a greater audience and written in a rather clear fashion to transport preferences to the electorate (Budge, 2001). The manifestos have been retrieved from the raw data of the CMP project, the database of polidoc.net and directly from parties. ${ }^{3}$

The cases for this study are four higher education systems from four different European countries, England ${ }^{4}$, the German Bundesland of North Rhine-Westphalia (NRW), Norway and the Netherlands. As HE policy in Germany is within the competences of the Bundes/änder, it is necessary to analyze it on this level, and NRW was chosen because it is the largest federal state.

These HE systems and countries were selected based on their variation in relation to three characteristics. First, they differ with regard to the number of relevant parties. This is important because the level of polarization of a party system impacts partisan competition. Second, the chosen countries represent three different welfare state regimes, which have been found to impact the development of matching education regimes and thus different institutional settings (Busemeyer, 2015). Finally, the HE systems that are included also cover three different types of

\footnotetext{
${ }^{1}$ A coding example is added in the appendix.

${ }^{2}$ Three months after the initial coding an intra-coder reliability test was conducted using $10 \%$ of the corpus. Based on Holsti's (1969) method the proportion agreement observed was .80. Krippendorff's alpha was calculated at .7981 (Hayes and Krippendorff, 2007).

${ }^{3}$ The detailed list of manifestos is in the appendix.

${ }^{4}$ In the UK the focus is on England, as Scotland and Wales can formulate separate HE policies.
} 
historical HE regimes, Anglo-Saxon, Nordic and Humboldtian, which accounts for variation in institutional settings (Christensen et al., 2014; Clark, 1983).

Table 2. Overview of included manifestos.

\begin{tabular}{|c|c|c|c|c|}
\hline Country & $\begin{array}{l}\text { Election } \\
\text { year }\end{array}$ & Parties & $\begin{array}{l}\text { Total number of } \\
\text { coded positions } \\
\text { per manifesto }\end{array}$ & Manifestos \\
\hline \multirow[t]{2}{*}{ UK } & 2005 & $\begin{array}{l}\text { Conservative, Labour, } \\
\text { Liberal Democrats }\end{array}$ & $7,11,4$ & $\begin{array}{l}\text { Con1, Lab1, } \\
\text { LibDem1 }\end{array}$ \\
\hline & 2010 & $\begin{array}{l}\text { Conservative, Labour, } \\
\text { Liberal Democrats }\end{array}$ & $5,20,10$ & $\begin{array}{l}\text { Con2, Lab2, } \\
\text { LibDem2 }\end{array}$ \\
\hline \multirow[t]{2}{*}{ NRW } & 2005 & $\begin{array}{l}\text { SPD, CDU, FDP, Grüne, } \\
\text { WASG }^{5}\end{array}$ & $\begin{array}{l}13,24,47,13, \\
10\end{array}$ & $\begin{array}{ll}\text { SPD1, } & \text { CDU1, } \\
\text { FDP1, } & \text { Grü1, } \\
\text { WASG1 } & \end{array}$ \\
\hline & 2010 & $\begin{array}{l}\text { SPD, CDU, FDP, Grüne, Die } \\
\text { Linke }\end{array}$ & $23,10,58,34,6$ & $\begin{array}{ll}\text { SPD2, } & \text { CDU2, } \\
\text { FDP2, } & \text { Grü2, } \\
\text { Linke2 } & \end{array}$ \\
\hline \multirow[t]{2}{*}{ Norway } & 2009 & $\begin{array}{l}\text { AP, FrP, Høyre, KrF, SenP, } \\
\text { SV, Venstre }\end{array}$ & $\begin{array}{l}24,24,32,40, \\
41,36,38\end{array}$ & $\begin{array}{l}\text { AP1, FrP1, Høy1, } \\
\text { KrF1, SenP1, SV1, } \\
\text { Ven1 }\end{array}$ \\
\hline & 2013 & $\begin{array}{l}\text { AP, FrP, Høyre, KrF, SenP, } \\
\text { SV, Venstre }\end{array}$ & $\begin{array}{l}23,22,22,40, \\
13,39,26\end{array}$ & $\begin{array}{l}\text { AP2, FrP2, Høy2, } \\
\text { KrF2, SenP2, SV2, } \\
\text { Ven2 }\end{array}$ \\
\hline Netherlands & 2010 & $\begin{array}{l}\text { CDA, CU, D66, GroenLinks } \\
\text { (GL), PvdA, PVV, SGP, SP, }\end{array}$ & $\begin{array}{l}25,12,25,14, \\
24,6,17,10,16\end{array}$ & $\begin{array}{l}\text { CDA1, CU1, D66- } \\
\text { 1, GL1, PvdA1, }\end{array}$ \\
\hline
\end{tabular}

\footnotetext{
${ }^{5}$ In 2005 both the WASG and the PDS ran as separate parties, with WASG being the more successful one. In
} 2010 both parties merged into the new party Die Linke. 


\begin{tabular}{|l|l|l|l|l|}
\hline & & & & \\
& & & & PVD1, SGP1, SP1, \\
& 2012 & CDA, CU, D66, GroenLinks & $16,20,24,12$, & CDA2, CU2, D66- \\
& (GL), PVdA, PVV, SGP, SP, & $34,3,18,15,26$ & 2, GL2, PvdA2, \\
& VVD & & PVV2, SGP2, SP2, \\
& & & & VVD2 \\
\hline
\end{tabular}

\section{Partisan HE policy positions}

This section presents the results of the analysis organized by party families. A complete tabular overview of the partisan positions for each country is provided in the appendix.

\section{Social Democrats}

On the re-distributive dimension, UK's Labour proposes to increase access concerning entrance qualifications and student numbers (Lab1: 41; Lab2: 3-7). Regarding private spending, they advocate in 2005 to continue their policy of a maximum tuition of 3,000 GBP. They also support increased public spending and the expansion of support for students from disadvantaged families. In 2010 Labour proposes to enlarge student support and public funding, but does not address private spending. Except for their general support for the existing level of tuition fees, Labour's policies are in line with the expectation to favor an expansive HE system. The support for a limited tuition fee can be a path dependency stemming from the existing HE system. As the tuition fees are combined with the demand for more support especially for students from poorer backgrounds, their restrictive effect on access to $\mathrm{HE}$ is diminished. Labour does not take a position on the control dimension. Such lack of party competition on this dimension is not surprising, considering that ideas of New Public Management have been embraced early on in the UK (Christensen, 2011), and that the British 2.5 party-system favors political conflicts along one dimension rather than multiple dimensions. 
The SPD in NRW shows preferences on the re-distributive dimension that are in line with the conceptual expectations. They are against tuition fees, support increased access to HE and more public funding and student support (SPD1: 6; SPD2: 19ff). With regard to HE governance, the SPD shows a mixed profile. While some positions are in line with the expectations - more involvement of stakeholders, in particular internal ones like students and highlighting the role of the government in HE governance (SPD1: 6; SPD2: 21) - they also propose especially in 2005 increased autonomy of universities. Here the strong role of the government in HE governance in Germany is relevant; the proposal of the SPD in 2005 to give universities more autonomy upholds the principle of a strong government influence by transferring only a limited amount of competencies. Furthermore, in 2010, after CDU and FDP had implemented their autonomy-oriented reforms, the SPD opposes most of these reforms.

The Norwegian AP fulfills the expectations by supporting expansive HE. They are against tuition fees, in favor of more public spending and increased student support (AP1: 24ff; AP2: 30). On the control dimension AP promotes, as expected, a stronger role of the government, combined with stakeholder involvement (AP1: 25ff; AP2: 30).

The Dutch PvdA also fulfills the expectations on the re-distributive dimension. They support an increase in public funding, a shift of the student support system to loans combined with scholarships for disadvantaged students, , abolishing fees for studying longer, and increased student numbers (PvdA1: 26f; PvdA2: 9f\&20). With regard to the control of HE, PvdA focuses, as expected, mainly on a strong governmental role and in 2012 also on stakeholder involvement.

\section{Christian Democrats}

The preferences of the Christian Democrats show some variation from the conceptual expectations. In relation to the re-distributive dimension, the CDU in NRW promotes increased private spending by introducing tuition fees up to 500 Euros per semester as well as a limited expansion of student support (CDU1: $21 ;$ CDU2: 8 ). While the first position is in line with the 
expectations, the CDU's support for more student support contradicts them. Here the existing $\mathrm{HE}$ system can be seen as a constraint: because the proposal to introduce tuition fees is groundbreaking (there were no general tuition fees thus far), aligning it with an increase in student support is expected to limit opposition. However, as the increase in student support is mainly loanbased, additional public costs and the expansive effect on the HE system are limited. The CDU also proposes in 2005 to initiate a review of the federal regulation on access to universities with the intention to limit the number of newly enrolled students (CDU1: 21). This is in line with a restrictive HE system. In 2010 CDU proposes to expand public spending, increase student numbers, and widen access for people with vocational qualifications (CDU2: 8f). This seemingly contradicts their preference for a more restrictive HE system; however, because the increase in student numbers is linked to an expected rise in the number of secondary school graduates, it mainly serves the purpose to keep the relative level of participation stable.

On the control dimension, the CDU mainly supports more autonomy of HE institutions. However, they also stress the need for a diminished role of the state and propose a limited amount of market mechanisms to be introduced (CDU1: 21).

The position of the Norwegian $\mathrm{KrF}$ on the re-distributive dimension, increasing student support and opposing private spending, contradicts expectations, as they do not support a restrictive HE system. However, this discrepancy can be contextualized. First, it is questionable whether a really restrictive HE system is per se a viable policy option in a Nordic welfare state. Second, the support of $\mathrm{KrF}$ for more public funding can be linked to the exceptionally good funding situation of the Norwegian public sector. Third, the well-funded public sector and the Nordic Model also explain the position in favor of more student support as positive feedback effects prevent them from taking a restrictive position (Garritzmann, 2015). KrF's position on the control dimension also only partly fits the expectations. While their focus on the coherence of educational offerings throughout 
the country and thus an active role of the government fits the expectations (KrF1: 71ff; KrF2: 61ff), they lack the expected support for more institutional autonomy of HE institutions.

The Dutch Christian Democratic Appeal (CDA) by and large fulfills the expectations with regard to the re-distributive dimension. They plan to increase private spending and support more public spending, but only in relation to areas of excellence (CDA1: 28ff; CDA2: 45f). Contrary to the expectations, CDA supports to keep the grant-based student support system stable. The second Dutch party, the Christian Union (CU), has a similar profile. They support higher tuition fees, but also more general public spending (CU1: 26; CU2: 31), as well as grant-based student support. The third party, the orthodox Calvinist SGP, has a comparable policy profile as CDA and CU, supporting an increase in fees and general public spending (SGP1: 18f; SGP2: 10), but favoring a diversified support system with additional student loans. All three, as expected, support a more restrictive HE system. On the control dimension, the three parties support, as expected, more autonomy for HE institutions. While the CU completely fulfills the conceptual expectations, the CDA and the SGP combine the focus on autonomy with more market mechanisms.

\section{Conservatives}

The British Conservatives have a mixed profile with regard to the re-distributive dimension. Concerning private HE spending, they propose in 2005 to abolish tuition fees introduced by Labour, but in 2010 support the Browne Report which argued for significantly higher tuition fees (Shattock, 2012: 166f), thus supporting an increase of private spending (Con1: 9; Con2: 17). Their only preference concerning access to HE is proposing 10,000 new study places in 2010 . While the support for an increase in tuition in 2010 is in line with the conceptual expectations, the limited expansion in student numbers and especially the anti-tuition fee policy of the Conservatives in 2005 is contradicting them. However, compared to the other two parties in England the Conservatives still show the most restrictive preferences on the re-distributive dimension. Furthermore, their proposal to abolish tuition can be seen as a constrained stemming from the ' 2.5 
party system' which creates an incentive to propose opposing policy solutions instead of using issue saliency to distance oneself from other parties. In relation to the control dimension, the Conservatives comply with the conceptual expectations, as they support the autonomy of HE institutions and market mechanisms and thus decentralized control (Con1: 9; Con2: 17).

As in the previously mentioned case of $\mathrm{KrF}$, also the position on the re-distributive dimension of the Norwegian Høyre is somewhat contradictory, as they do not support a restrictive HE system. However, the same contextualization that was outlined with regard to $\mathrm{KrF}$ is also valid for $\mathrm{H} \varnothing \mathrm{yre}$. Notably, $\mathrm{H} \varnothing \mathrm{yre}$ also propsoes to increase the cap on personal income with which students are still eligible for student support, and strengthen the rights of students in private HE institutions ( $\mathrm{\varnothing} \varnothing \mathrm{y}$ : 9ff; Høy2: 15ff). Additionally, Høyre is one of only two parties that do not position themselves against tuition fees in either of their manifestos. Thus, in the context of Norway, Høyre can be seen as partially fulfilling the expectations towards CPs; they take the most restrictive position in a political debate generally geared towards expanding HE. Concerning the control of HE Høyre favors market mechanisms and autonomy of HE institutions and thus fits the de-centralized expectations.

\section{Liberals}

The UK Liberal Democrats show stable preferences on the re-distributive dimension in relation to private spending, opposing tuition fees (LibDem1: 12; LibDem2: 39). At the same time, they want to enlarge student support and have wider access. The policies proposed by the Liberal Democrats are partially in line with the expectations; however, while supporting an expansive HE system, they do not support private funding. One explanation for this discrepancy is that by opposing tuition fees they are able to acquire a distinct political profile that separates them from the other parties. The Liberal Democrats only address the control dimension it in 2010 and favor, as expected, decentralization and more autonomy for HE institutions (LibDem2: 29).

The FDP in NRW supports on the re-distributive dimension increased private spending by introducing tuition fees up to 500 Euros per semester (FDP1: 17ff; FDP2: 14ff) as well as a limited 
expansion of student support. They additionally focus on providing more merit-based grants, financed by private benefactors. The FDP also promotes more public spending and in 2010 wider access to HE. While their proposal to expand student support using merit-based measures fits the expectations for LPs, their HE policies are not as expansive as it would be expected. With regard to the control dimension the FDP confirms the expectations, supporting de-centralization through markets and autonomy for universities (FDP1: 17ff; FDP2: 14ff).

Generally, two consensual policy issues can be identified in Norway: (1) the need to spend more public money on $\mathrm{HE}$, and (2) the need to enlarge student support. The introduction of private spending in the form of tuition fees for public universities is a taboo and no party promotes it, while many actively oppose the idea. In line with this, the Norwegian Venstre, fulfills the expectations only partially, as they do not promote private spending while supporting expansive $\mathrm{HE}$ (Ven1: 29ff; Ven2: 17ff).On the control dimension, Venstre favors market mechanisms and autonomy of HE institutions, which fits the expectations.

The two liberal parties in the Netherlands show differing profiles. The preferences of the VVD are in line with the expectations: more public spending, more access, allowing universities to determine fees (thus increasing private spending), and a shift from grants to loans in student support (VVD1: 13\&17; VVD2: 24f). The second party D66 supports a more expansive HE system than VVD, but also includes private HE spending. They advocate an increase in public funding to improve the quality of education (financed by a shift from grants to loans), combined with increased grants for students from disadvantaged backgrounds, increase of tuition fees for secondary degrees and abolishing fees for students who study longer (D66-1: 37ff; D66-2: 24ff). With regard to the control dimension, both VVD and D66 fulfill the conceptual expectations supporting de-centralization through more autonomy and market. 
Greens

The Greens in NRW show preferences on the re-distributive dimension which are in line with the expectations, as they support increased public spending, student support and access while opposing tuition fees (Grü1: 92ff; Grü2: 80ff). Also on the control dimension the Greens in NRW comply with the conceptual expectations by supporting the involvement of stakeholders combined with the demand for a strong role of the government (Grü1: 92ff; Grü2: 80ff).

The Dutch GroenLinks fulfill the expectations. In 2010 they support a limited increase in public spending and suggest a "student wage" for every student to enhance access (GL1: 24ff), a position maintained in 2012 through a focus on life-long learning and adult education in HE (GL2: 17f). Overall, their idea is to limit private spending and increase public spending, shifting student support from grants to loans while increasing the number of grants for disadvantaged students. Also on the control dimension GroenLinks fulfills the expectations, as they support central government control.

\section{Anti-establishment parties}

On the left fringe of the political spectrum, Die Linke / WASG in NRW shows preferences on the redistributive dimension which are in line with the expectations as they oppose tuition fees and favor increasing student support and public spending (WASG1). On the control dimension they argue, as expected, for more central state control of the HE sector, combined with the involvement of stakeholders (Linke2: 11f).

The Norwegian SV fulfills the expectations on the re-distributive dimension supporting an expansive HE system with increased public spending, student support and access (SV1: 17ff; SV2: 51ff). On the control dimension SV supports, as expected, a stronger central control of the government combined with stakeholder involvement (SV1: 17ff; SV2: 51ff).

The Dutch SP, as expected, supports an expansive HE system, increasing public spending, keeping the grant system and expanding it for disadvantaged students. In 2010 they propose to increase 
access to HE, while opposing the idea of differentiated fees (SP1: 25f), and in 2012 they proposes to limit private spending (SP2: 31ff). Also on the control dimension SP fulfills the expectations by supporting centralized governance.

At the right end of the political spectrum, the Norwegian FrP fulfills the expectations of supporting an expansive HE system with increased public spending and student support (FrP1: 62ff; FrP2: 70ff). Concerning the governance of HE FrP promotes de-centralized market mechanisms and autonomy of $\mathrm{HE}$ institutions. This does not fit the expectations, but rather resembles the profile of a CP. Additionally FrP also has a quite elaborate section on HE policy in both manifestos. This illustrates the normalization of FrP in recent years (Allern, 2010: 211f).

The Dutch PVV offers barely any positions on HE. Concerning re-distribution they propose that all foreign students should pay tuition, leading to a limited increase in private spending (PVV1: 29ff; PVV2: 43ff). Furthermore, they want to keep the student support system stable. With regard to control, PVV supports de-centralization through autonomy of universities, which is not in line with the expectations. However, the limited amount of preferences makes it hard to definitively position PVV on either dimension.

\section{Others}

Due to the small number of existing European Farmers' Parties, no conceptual expectations have been formulated. The Norwegian SenP favors on the re-distributive dimension an expansion of the system. However, they support an increase in the number of students only in relation to economically important subjects and refrain from positioning themselves against tuition fees (SenP1: 40ff; SenP2: 59ff). This position is in line with their profile as a protector of the Norwegian welfare state but also encompasses their orientation to more conservative economic policies (Allern, 2010: 172). On the control dimension SenP supports central control and a dominant role of the government with a focus on stakeholder involvement, especially concerning representatives of 
the municipalities (SenP1: 40ff; SenP2: 59ff).Overall, SenP's policies on HE governance fit their profile of being a left-leaning non-urban party (Allern, 2010: 172f).

\section{Comparing the results}

Based on the detailed analysis above it is possible to compare the partisan preferences in the four countries. Table 3 provides such a comparison including a further separation of each of the 4 cells to highlight differences within a cell:

Table 3. Comparison of partisan preferences in HE.

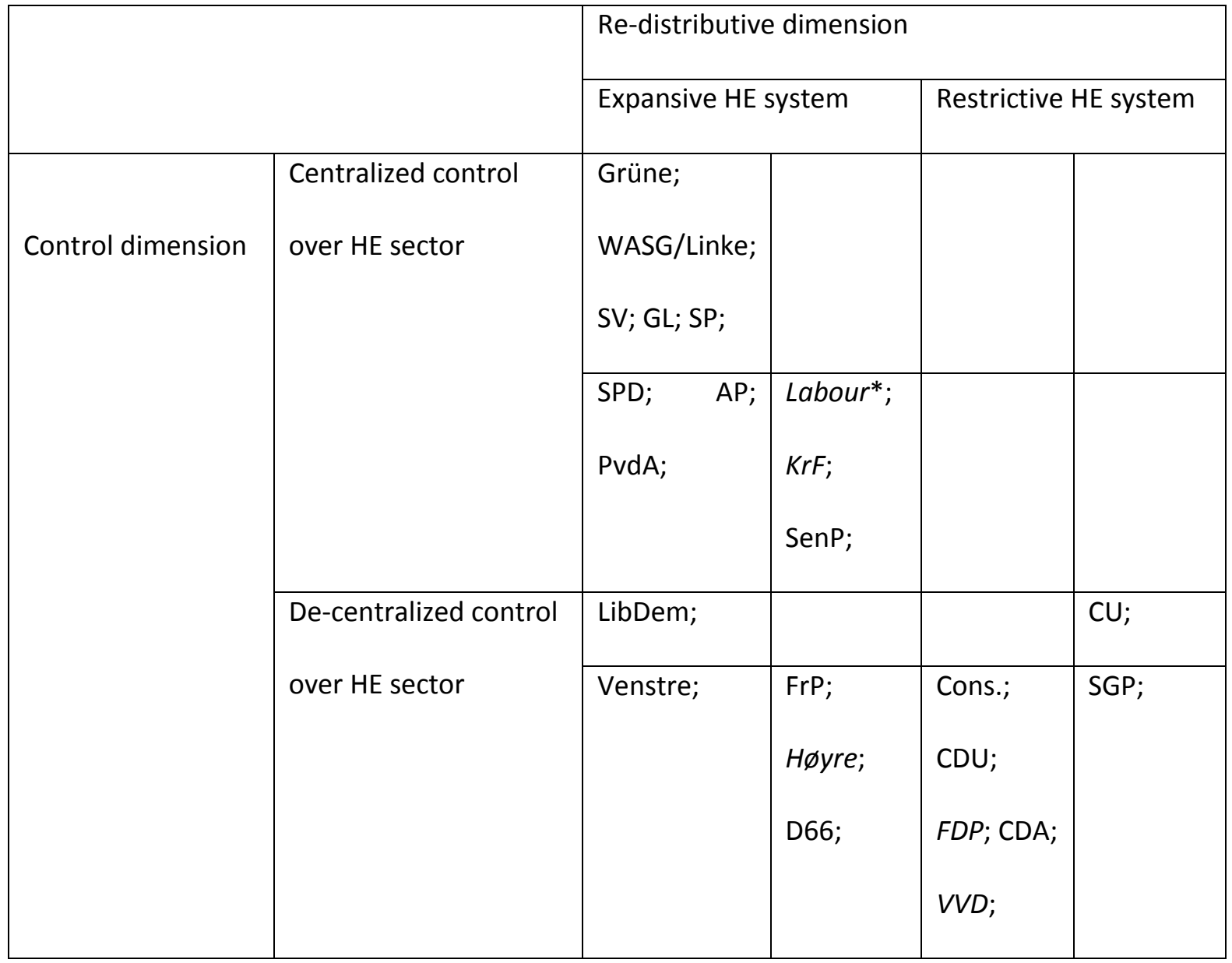

* Labour does not describe a preference on the control dimension.

Parties in italics deviate from the theoretical expectations.

A comparison between the expectations and the empirical results shows that generally speaking the partisan preferences vary accordingly. The evidence supports the two-dimensionality of partisan preferences on HE. However, there is also a fair amount of variation within party families 
and between countries, suggesting that the additional factors that have been addressed at the end of the conceptual frame also matter.

The Norwegian $\mathrm{KrF}$ and Høyre show a preference on the re-distributive dimension that is more in favor of an expansive higher education system, while they should support a more restrictive system. As pointed out earlier this diverging preference can be explained with the context in which the parties position themselves. The party competition in Norway can be characterized as limited, due to inter-party consensus, in particular, related to the re-distributive dimension. This absence of intense political competition on the re-distributive dimension is linked to already high participation in $\mathrm{HE}$ and steady income from oil and gas leading to ample public funding. As the Nordic Model of HE (Christensen et al., 2014) is in general based on expansive HE, it is unlikely for parties in these countries, even if they are more opposed to re-distribution, to position themselves in favor of a restrictive $\mathrm{HE}$ system. So while $\mathrm{KrF}$ and $\mathrm{H} \varnothing y r e$ offer the most restrictive preferences on the redistributive dimension in Norway, in comparison to the other parties with similar ideological backgrounds they can be seen to hold a more expansive position.

This diverging preferences of parties from a similar ideological background underline the importance of the existing higher education sector as a reference frame that parties relate to and that constrains their preferences (Gingrich, 2011: 35-44). Another example for such a situation is the more restrictive position of the English Labour Party compared to the other Social Democrats.

A second group with partly diverging preferences is the Liberals. While the Norwegian Venstre, the Dutch D66 and the UK's Liberal Democrats comply with the expectations, the German FDP and the Dutch VVD show more restrictive re-distributive preferences. As D66 and VVD form their preferences in the same national context the above explanation of constrained partisan preferences due to the existing HE system is not sufficient to explain these differences. This divergence can rather be explained by the partisan heterogeneity within the group of LPs (Kirchner, 1988). As pointed out by Garritzmann (2014: 254) different groups of liberal parties can be 
identified to hold differing positions on the re-distributive potential of HE. Economic liberal parties, for example, are more restrictive in their preference than social liberal parties. Thus, the spread of different liberal parties along the re-distributive dimension in the results of this analysis mirrors these earlier findings.

The Christian Democrats also show a spread in preferences which is mainly related to the control dimension. The positions range from a preference for rather centralized control by KrF to very decentralized control and a focus on market competition by CDA, SGP and CDU. As pointed out in the conceptual section, CDs unite a preference for subsidiarity with one supporting the government's power to assure even quality of public services. The differences between the parties can be seen as a representation of those differing roots, and given the distribution of the CDs on the control dimension it seems that the principle of subsidiarity has a stronger influence. Finally, it needs to be pointed out that the Dutch PVV was not included in table 3 because they did not offer enough substantive preferences for a clear position.

\section{Conclusion}

The findings presented in this article confirm that also in a more specialized policy area like HE parties have differing preferences. These preferences are structured along two dimensions, a redistributive and one linked to public governance. As the existing research, not only on HE but on social policy in general, focuses on re-distribution as the main conflict line (e.g. Ansell, 2010; Busemeyer, 2009; Boix, 1997), the two-dimensionality of the partisan competition is a central contribution of this study. It stresses that one cannot adequately understand partisan preferences on core public sector policies without taking into consideration public governance. Given the growing importance of NPM and post-NPM reforms, the political conflicts around the question of how to control public sectors have gained saliency and parties matter for the configuration of the state-public sector relationship. Research on this is still rather limited (see: Gingrich, 2011; 
Gingrich, 2015) and therefore the results of this study offer ample opportunities for follow-up work.

The theoretical expectations, based on the ideological background and constituents of the different party families, have in general been confirmed. However, the partisan positions also showed a fair amount of variation. This highlights the importance of factors such as the party competition, institutional settings or policy legacies for the formulation of partisan preferences, as they create constrains that lead to diverging positions within party families.

Additionally, both LPs as well as CDs show rather diverse positions. While in the case of LPs this is mainly in relation to the re-distributive dimension, $\mathrm{CDs}$ vary along the control dimension. In both cases the divergence within the group seems to be linked to the diverse ideological background, therefore it is necessary to further unpack the differences within the party family. AEPs especially on the right fringe of the political spectrum had very few formulated preferences on $\mathrm{HE}$ and thus were harder to relate to the theoretical expectations. A comparison between the more refined positions of the Norwegian FrP and the very limited preferences of the Dutch PVV points towards the idea that the normalization of FrP might be the reason for their more detailed preferences. This assumption needs further exploration with a broader empirical basis. Finally, the qualitative approach chosen for this study and the limited number of countries included in the empirical material put certain limitations on the transferability of the results. While the foundation of the conceptual expectations in the broader party politics literature should make the results transferable to other stable parliamentary democracies, it is more likely for partisan dynamics to differ in unstable ones. This demands further research also outside the usual OECD context.

\section{Acknowledgements}

to be added 


\section{Literature}

Allern EH. (2010) Political parties and interest groups in Norway, Colchester: ECPR Press.

Ansell BW. (2010) From the Ballot to the Blackboard : the Redistributive Political Economy of Education, Cambridge: Cambridge University Press.

Boix C. (1997) Political Parties and the Supply Side of the Economy: The Provision of Physical and Human Capital in Advanced Economies, 1960-90. American Journal of Political Science 41: 814-845.

Budge I. (2001) Validating Party Policy Placements. British Journal of Political Science 31: 210-223.

Busemeyer MR. (2009) Social democrats and the new partisan politics of public investment in education. Journal of European Public Policy 16: 107-126.

Busemeyer MR. (2015) Skills and Inequality. Partisan Politics and the Political Economy of Education Reforms in Western Welfare States, Cambridge: Cambridge University Press.

Busemeyer MR, Franzmann ST and Garritzmann JL. (2013) Who Owns Education? Cleavage Structures in the Partisan Competition over Educational Expansion. West European Politics 36: 521-546.

Callender C and Jackson J. (2005) Does the Fear of Debt Deter Students from Higher Education? Journal of Social Policy 34: 509-540.

Christensen T. (2011) University governance reforms: potential problems of more autonomy? Higher Education 62: 503-517.

Christensen T, Gornitzka Å and Maassen P. (2014) Global Pressures and National Cultures. A Nordic University Template? In: Mattei P (ed) University Adaptation in Difficult Economic Times. Oxford: Oxford University Press, 30-51.

Clark BR. (1983) The higher education system: academic organization in cross-national perspective, Berkeley, Calif.: University of California Press.

Fernandez R and Rogerson R. (1995) On the Political Economy of Education Subsidies. The Review of Economic Studies 62: 249-262. 
Garritzmann JL. (2014) The Political Economy of Higher Education Finance - A Comparative Analysis of the Politics of Tuition Fees and Subsidies. Department of Politics and Public Administration. Konstanz: University of Konstanz.

Garritzmann JL. (2015) Attitudes towards student support: How positive feedback-effects prevent change in the Four Worlds of Student Finance. Journal of European Social Policy.

Gingrich JR. (2011) Making markets in the welfare state: the politics of varying market reforms, Cambridge: Cambridge University Press.

Gingrich JR. (2015) Varying Costs to Change? Institutional Change in the Public Sector. Governance 28: 41-60.

Gornitzka Å and Maassen P. (2000) Hybrid steering approaches with respect to European higher education. Higher Education Policy 13: 267-285.

Hayes AF and Krippendorff K. (2007) Answering the Call for a Standard Reliability Measure for Coding Data. Communication Methods and Measures 1: 77-89.

Heywood A. (2007) Political ideologies : an introduction, New York: Palgrave Macmillan.

Hibbs DAJ. (1977) Political Parties and Macroeconomic Policy. American Political Science Review 71: $1467-1487$.

Holsti OR. (1969) Content analysis for the social sciences and humanities, Reading, Mass.: AddisonWesley.

Kalyvas SN and van Kersbergen K. (2010) Christian Democracy. Annual Review of Political Science 13: 183-209.

Kirchner EJ. (1988) Liberal parties in Western Europe, Cambridge: Cambridge University Press.

Kriesi H. (2010) Restructuration of Partisan Politics and the Emergence of a New Cleavage Based on Values. West European Politics 33: 673-685.

Laver M, Benoit K and Garry J. (2003) Extracting Policy Positions from Political Texts Using Words as Data. American Political Science Review 97: 311-331. 
Olsen JP. (1988) Administrative reform and theories of organization. In: Campbell C and Peters BG (eds) Organizing governance, governing organizations. Pittsburgh: University of Pittsburgh Press, 233-254.

Pierson P. (1993) When Effect Becomes Cause: Policy Feedback and Political Change. World Politics 45: 595-628.

Pollitt C. (2001) Clarifying Convergence. Striking similarities and durable differences in public management reform. Public Management Review 3: 471-492.

Rauh C, Kirchner A and Kappe R. (2011) Political Parties and Higher Education Spending: Who Favours Redistribution? West European Politics 34: 1185-1206.

Sartori G. (1976) Parties and party systems, Cambridge: Cambridge University Press.

Schmidt MG. (2007) Testing the retrenchment hypothesis: educational spending, 1960-2002. In: Castles FG (ed) The Disappearing State? Retrenchment Realities in an Age of Globalisation. Cheltenham: Edward Elgar, 159-183.

Schofer E and Meyer JW. (2005) The Worldwide Expansion of Higher Education in the Twentieth Century. American Sociological Review 70: 898-920.

Shattock M. (2012) Making policy in british higher education: 1945 -2011, Maidenhead: Open University Press.

Volkens A. (2007) Strengths and weaknesses of approaches to measuring policy positions of parties. Electoral Studies 26: 108-120.

Volkens A, Bara J, Budge I, et al. (2014) Mapping policy preferences from texts: statistical solutions for manifesto analysts, Oxford: Oxford University Press.

Wolf F and Zohlnhöfer R. (2009) Investing in human capital? The determinants of private education expenditure in 26 OECD countries. Journal of European Social Policy 19: 230-244. 


\section{APPENDIX}

\section{CODING EXAMPLE}

„We want to continue to increase the percentage of incoming students and graduates and bring it up to the international average." [SPD 2005]

Coded as: Access to HE - Increase

\section{LIST OF MANIFESTOS}

Arbeiderpartiet (2009). Skape og dele. Arbeiderpartiets program 2009 - 2013. (AP1)

Arbeiderpartiet (2013). Vi tar Norge videre. Arbeiderpartiets program 2013-2017. (AP2)

CDA (2010). Slagvaardig en samen. Verkiezingsprogram 2010-2015. (CDA1)

CDA (2012). ledereen. Verkiezingsprogramma 2012-2017. (CDA2)

CDU (2005). Zukunftsprogramm der CDU Nordrhein-Westfalen. (CDU1)

CDU (2010). Neue Sicherheit und Solidarität. Nordrhein-Westfalen 2020. (CDU2)

ChristenUnie (2010). Vooruitzien Christelijk-sociaal perspectief. Verkiezingsprogramma ChristenUnie 2010-2014. (CU1)

ChristenUnie (2012). Voor de verandering. 7 christelijk-sociale hervormingen.

Verkiezingsprogramma 2013-2017. (CU2)

Conservatives (2005). It's time for action. Conservative Election Manifesto 2005. (Con1)

Conservatives (2010). Invitation to join the government of Britain. The Conservative Manifesto 2010. (Con2)

D66 (2010). We willen het anders. Verkiezingsprogramma D66 voor de Tweede Kamer 2010 - 2014. (D66-1)

D66 (2012). En nu vooruit. Op weg naar een welvarende, duurzame toekomst.

Verkiezingsprogramma D66 voor de Tweede Kamer 2012 / 2017. (D66-2)

Liberal Democrats (2005). The REAL alternative. (LibDem1)

Liberal Democrats (2010). Liberal Democrat Manifesto 2010. (LibDem2)

FDP (2005). Das neue NRW. Wahlprogramm zur Landtagswahl in Nordrhein-Westfalen am 22.Mai 2005. (FDP1)

FDP (2010). Aufsteigerland NRW. Das Programm zur nordrhein-westfälischen Landtagswahl 2010. (FDP2)

Fremskrittspartiet (2009). Handlingsprogram 2009-2013. (FrP1)

Fremskrittspartiet (2013). Handlingsprogram 2013-2017. (FrP2)

GroenLinks (2010). Klaar voor de toekomst. Verkiezingsprogramma 2010. (GL1)

GroenLinks (2012). Groene kansen voor Nederland. Verkiezingsprogramma 2012. (GL2)

BÜNDNIS 90/DIE GRÜNEN (2005). Landtagswahlprogramm 2005 DIE GRÜNEN NRW. (Grü1)

BÜNDNIS 90/DIE GRÜNEN (2010). Zukunftsplan für NRW. Das Programm zur Landtagswahl 2010. (Grü2)

Høyre (2009). Muligheter for alle. Høyres Stortingsvalgprogram 2009-2013. (Høy1)

Høyre (2013). Nye ideer, bedre løsninger. Høyres stortingsvalgprogram 2013-2017. (Høy2)

Kristelig Folkeparti (2009). KrFs program 2009 -2013. (KrF1)

Kristelig Folkeparti (2013). Politisk program 2013-2017. (KrF2)

Labour (2005). Britain forward not back. The Labour Party manifesto 2005. (Lab1)

Labour (2010). The Labour Party Manifesto 2010. A future fair for all. (Lab2)

DIE LINKE (2010). Original sozial - konsequent solidarisch. Das Landeswahlprogramm 2010. (Linke2) 
PvdA (2010). ledereen telt mee. De kracht van Nederland. PvdA verkiezingsprogramma 2010.

(PvdA1)

PvdA (2012). Nederland Sterker \& Socialer. Verkiezingsprogramma Tweede Kamerverkiezingen 2012. (PvdA2)

PVV (2010). De agenda van hoop en optimisme. Een tijd om te kiezen: PVV 2010-2015. (PVV1)

PVV (2012). Hún Brussel, óns Nederland. Verkiezingsprogramma 2012 - 2017. (PVV2)

Senterpartiet (2009). Senterpartiets program 2009-13. (SenP1)

Senterpartiet (2013). Prinsipp- og handlingsprogram 2013-2017. (SenP2)

SGP (2010). Daad bij het Woord: de SGP stáát ervoor! Verkiezingsprogramma SGP 2010 -2014. (SGP1)

SGP (2012). Verkiezingsprogramma SGP 2012-2017. (SGP2)

Sosialistisk Venstreparti (2009). SVs arbeidsprogram for perioden 2009-2013. (SV1)

Sosialistisk Venstreparti (2013). Del godene! Arbeidsprogram for Sosialistisk Venstreparti 20132017. (SV2)

SP (2010). Een better Nederland voor minder geld. Verkiezingsprogramma SP 2011-2015. (SP1)

SP (2012). Nieuw Vertrouwen. Verkiezingsprogramma SP 2013-2017. (SP2)

SPD (2005). Stärker werden. Menschlich bleiben. Wahlprogramm zur Landtagswahl am 22. Mai 2005. (SPD1)

SPD (2010). Unser NRW. Mutig. Herzlich. Gerecht. Programm zur Landtagswahl am 9. Mai 2010. (SPD2)

Venstre (2009). Frihet og ansvar. Et sosialliberalt samfunn. Venstres stortingsvalgprogram 20092013. (Ven1)

Venstre (2013). Frihet. Fremtid. Fellesskap. Venstres stortingsvalgprogram 2013-2017. (Ven2)

VVD (2010). Orde op zaken. Verkiezingsprogramma 2010-2014. (VVD1)

VVD (2012). Niet doorschuiven maar aanpakken. Verkiezingsprogramma VVD 2012-2017. (VVD2)

WASG (2005). Arbeit, soziale Gerechtigkeit und Bildung für alle. Für ein soziales NRW. WASG

Wahlprogramm zur NRW-Landtagswahl 2005. (WASG1) 


\section{OVERVIEW OF PARTISAN POSITIONS BY COUNTRY}

In the tables a plus sign symbolizes a party's support and a minus a party's opposition.

Party positions in the 2005 \& 2010 UK elections.

\begin{tabular}{|c|c|c|c|c|c|c|c|}
\hline & Indicators & $\begin{array}{l}\text { Conservative } \\
2005\end{array}$ & $\begin{array}{l}\text { Conservative } \\
2010\end{array}$ & $\begin{array}{l}\text { Labour } \\
2005\end{array}$ & $\begin{array}{l}\text { Labour } \\
2010\end{array}$ & $\begin{array}{l}\text { Lib } \\
\text { Dem } \\
2005\end{array}$ & $\begin{array}{l}\text { Lib } \\
\text { Dem } \\
2010\end{array}$ \\
\hline \multirow[t]{5}{*}{$\begin{array}{l}\text { Re- } \\
\text { distribution }\end{array}$} & $\begin{array}{l}\text { Public } \\
\text { spending }\end{array}$ & & & + & + & & \\
\hline & $\begin{array}{l}\text { Private } \\
\text { spending }\end{array}$ & - & + & $(+)$ & & - & - \\
\hline & $\begin{array}{l}\text { Access } \\
\text { (student } \\
\text { numbers) }\end{array}$ & & $(+)$ & + & + & & $(-)$ \\
\hline & $\begin{array}{l}\text { Access } \\
\text { (qualifications) }\end{array}$ & & & & + & & + \\
\hline & $\begin{array}{l}\text { Student } \\
\text { support }\end{array}$ & & & + & & + & + \\
\hline \multirow[t]{4}{*}{ Control } & $\begin{array}{l}\text { Government } \\
\text { control }\end{array}$ & & & & & & \\
\hline & $\begin{array}{l}\text { Autonomy of } \\
\text { HE institutions }\end{array}$ & + & + & & & & + \\
\hline & $\begin{array}{l}\text { Stakeholder- } \\
\text { based steering }\end{array}$ & & & & & & \\
\hline & $\begin{array}{l}\text { Market } \\
\text { mechanisms }\end{array}$ & + & & & & & \\
\hline
\end{tabular}


Party positions in the 2005 \& 2010 elections in NRW.

\begin{tabular}{|c|c|c|c|c|c|c|c|c|c|c|c|}
\hline & Indicators & $\begin{array}{l}\text { CDU } \\
2005\end{array}$ & $\begin{array}{l}\text { CDU } \\
2010\end{array}$ & $\begin{array}{l}\text { SPD } \\
2005\end{array}$ & $\begin{array}{l}\text { SPD } \\
2010\end{array}$ & $\begin{array}{l}\text { FDP } \\
2005\end{array}$ & $\begin{array}{l}\text { FDP } \\
2010\end{array}$ & $\begin{array}{l}\text { Grüne } \\
2005\end{array}$ & $\begin{array}{l}\text { Grüne } \\
2010\end{array}$ & $\begin{array}{l}\text { WASG } \\
2005\end{array}$ & $\begin{array}{l}\text { Linke } \\
2010\end{array}$ \\
\hline \multirow[t]{5}{*}{$\begin{array}{l}\text { Re- } \\
\text { distribution }\end{array}$} & $\begin{array}{l}\text { Public } \\
\text { spending }\end{array}$ & & + & + & + & + & + & + & + & + & \\
\hline & $\begin{array}{l}\text { Private } \\
\text { spending }\end{array}$ & + & + & - & - & + & + & - & - & - & - \\
\hline & $\begin{array}{l}\text { Access } \\
\text { (student } \\
\text { numbers) }\end{array}$ & - & + & + & + & & + & + & + & & \\
\hline & $\begin{array}{l}\text { Access } \\
\text { (qualifications) }\end{array}$ & & + & & + & & + & & + & & \\
\hline & $\begin{array}{l}\text { Student } \\
\text { support }\end{array}$ & + & + & & + & $(+)$ & $(+)$ & & + & + & \\
\hline \multirow[t]{4}{*}{ Control } & $\begin{array}{l}\text { Government } \\
\text { control }\end{array}$ & & & & + & & & + & + & & + \\
\hline & $\begin{array}{l}\text { Autonomy of } \\
\text { HE institutions }\end{array}$ & + & + & + & $(-)$ & + & + & & & & \\
\hline & $\begin{array}{l}\text { Stakeholder- } \\
\text { based steering }\end{array}$ & & & + & + & & & + & + & + & + \\
\hline & $\begin{array}{l}\text { Market } \\
\text { mechanisms }\end{array}$ & $(+)$ & & & & + & + & & & & \\
\hline
\end{tabular}


Party positions in the 2009 \& 2013 elections in Norway. 


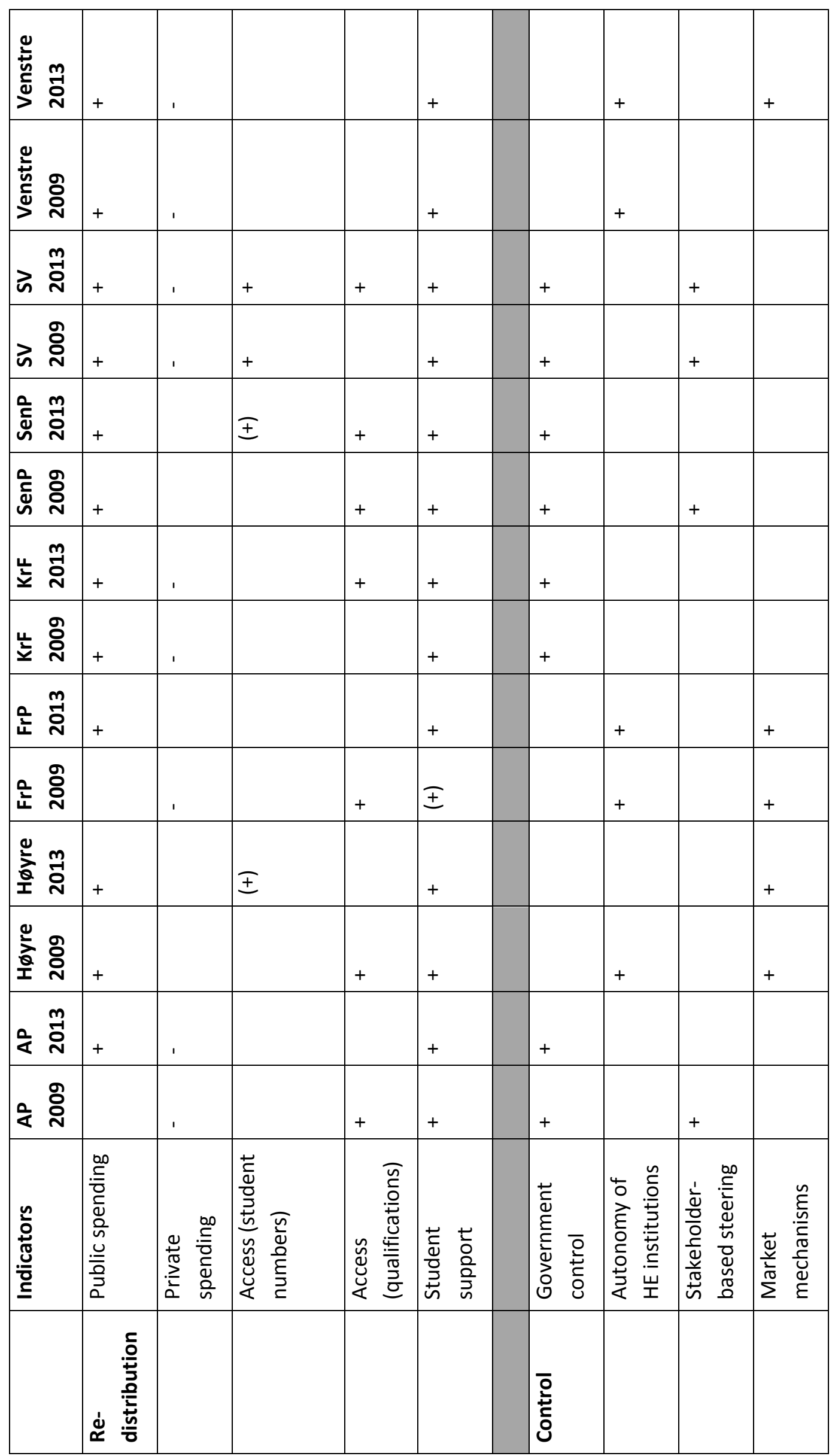


Party positions in the 2010 \& 2012 elections in the Netherlands. 


\begin{tabular}{|c|c|c|c|c|c|c|c|c|c|}
\hline $3 \stackrel{1}{3}$ & + & $\mp$ & $\mp$ & & $I$ & & + & & + \\
\hline ३) & + & + & & & $I$ & & + & & + \\
\hline n & + & , & & & + & + & & & \\
\hline is & + & $I$ & + & & $\Phi$ & & & & \\
\hline$\stackrel{\text { ڤ̆ }}{\tilde{N}}$ & + & + & & & \pm & & + & & + \\
\hline 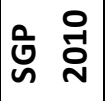 & + & + & & & $\Phi$ & & + & & \\
\hline$\sum_{a} \underset{\sim}{2}$ & & & & & $\Phi$ & & & & \\
\hline żo & & $\Phi$ & & & & & $\Phi$ & & \\
\hline$\frac{\mathbb{s}}{2} \underset{2}{2}$ & + & 1 & $\mp$ & & $\frac{T}{\underline{I}}$ & + & & + & \\
\hline 芯 : & + & & & & $\stackrel{T}{1}$ & + & & & \\
\hline త & + & , & & + & 交 & + & & & \\
\hline उ & $\mp$ & & & & + & + & & & \\
\hline ๕ั & + & $I$ & & $\Phi$ & $\frac{1}{1}$ & & + & & + \\
\hline : : & + & $\Phi$ & & & $I$ & & \pm & & + \\
\hline ૩ : ̃̃ & + & + & & & $\Phi$ & $\mp$ & $\Phi$ & & \\
\hline 乙 & & + & & & & + & & & \\
\hline ઢิ & + & + & & & \pm & & + & & + \\
\hline 品 : & + & + & & & $\Phi$ & & + & & + \\
\hline 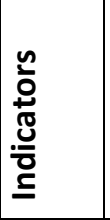 & 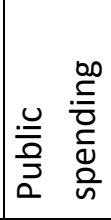 & 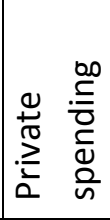 & 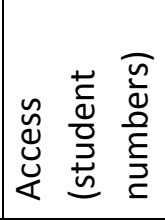 & 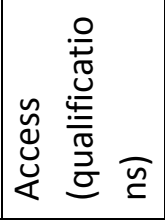 & 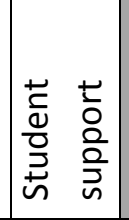 & 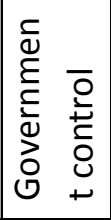 & 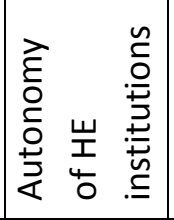 & 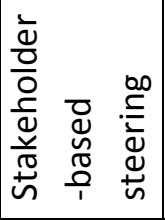 & 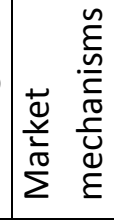 \\
\hline & 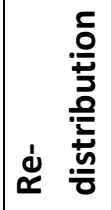 & & & & & 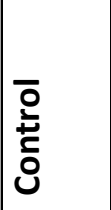 & & & \\
\hline
\end{tabular}

